\title{
Maternal Hyperglycemia and its Effect on the Placental Transport of Ascorbic acid ${ }^{(37,38)}$
}

\author{
EDWARD P. NORKUS, ${ }^{(39,40)}$ JORGE A. BASSI, AND PEDRO ROSSO \\ Institute of Human Nutrition and Department of Pediatrics, Babies Hospital, College of Physicians and Surgeons, \\ Columbia University, New York, New York U.S.A.
}

\begin{abstract}
Summary
This report explored the possibility that maternal hyperglycemia during pregnancy might produce a competition between glucose (G) and ascorbic acid (AA) and reduce the transfer of $\mathrm{AA}$ to the fetus using an in vivo single-pass placental perfusion technique in the guinea pig. Levels of $G$ in maternal plasma increased from 104 $\pm 4 \mathrm{mg} / \mathrm{dl}(\overrightarrow{\mathrm{x}} \pm \mathrm{S}$.E.) before $\mathrm{AA}+\mathrm{G}$ infusion to $370 \pm 19 \mathrm{mg} / \mathrm{dl}$ at the end of each study $(P<0.001)$. Preinfusion levels of $A A$ in maternal and fetal plasma were $0.29 \pm 0.02 \mathrm{mg} / \mathrm{dl}$ and $0.46 \pm 0.03$ $\mathrm{mg} / \mathrm{dl}$, respectively. Maternal infusion of AA or AA $+\mathrm{G}$ produced significant increases in maternal plasma $\mathrm{AA}(P<0.025)$ and fetal plasma AA $(P<0.001)$; however, fetal plasma AA from dams infused with $A A+G$ were significantly below fetal plasma values obtained when only $\mathrm{AA}$ was infused $(P<0.005)$ suggesting that when maternal plasma $G$ is increased, the placental transport of AA to the fetus is reduced. Preinfusion levels of AA in placental tissue were $10.8 \pm 0.5 \mathrm{mg} / \mathrm{dl}$ and infusion of $\mathbf{A A}$ or $\mathbf{A A}+\mathrm{G}$ produced significant increases in AA in this organ $(P<0.001)$. Comparison of the AA in placental tissue from fetuses of dams infused with either solution demonstrates that significantly less AA was present after $\mathrm{AA}+\mathrm{G}$ infusion $(\boldsymbol{P}<\mathbf{0 . 0 0 5})$. Additionally, when $A A+G$ was infused a significant decrease in $A A$ transferred across the placenta was found $(P<0.001)$ as maternal plasma $G$ increased beyond $200 \mathrm{mg} / \mathrm{dl}$. The data suggest that in the guinea pig glucose may compete with ascorbic acid transfer across the placenta and that maternal hyperglycemia may reduce the bioavailability of AA to the fetus.
\end{abstract}

\section{Speculation}

An acute episode of maternal hyperglycemia interferes with the placental transfer of ascorbic acid. Therefore, maternal hyperglycemia during gestational diabetes may result in a decreased supply of ascorbic acid to the fetus.

Ascorbic acid is present in all tissues of the body $(3,9)$. Among those tissues that have been studied, the uptake of this compound displays saturation kinetics $(4,7,10,11,20,24,26,28-33)$. Because most of these tissues also accumulate ascorbic acid against a concentration gradient, transport is believed to be carrier mediated and energy dependent. Recent reports indicate that glucose inhibits the uptake of ascorbic acid by red blood cells and heart endothelial cells in vitro $(17,34)$ and suggest that due to structural similarities, glucose and ascorbic acid compete for carrier sites on the cell surface. If this occurs in vivo, the hyperglycemia that accompanies overt diabetes could reduce the tissue uptake of ascorbic acid.

Previous reports from this laboratory indicate that ascorbic acid is transported across the placenta by a carrier-mediated mechanism in man and the guinea pig $(20,33)$. Because both species require ascorbic acid as a vitamin (3) the fetus relies totally on the placental transfer of ascorbic acid to supply its developmental and metabolic needs. Therefore, maternal hyperglycemia during preg- nancy might produce a competition between glucose and ascorbic acid for carrier sites on the placental membrane and reduce the transfer of ascorbic acid to the fetus. This report was designed to explore this possibility using an in vivo single-pass placental perfusion technique in the guinea pig.

\section{MATERIALS ·AND METHODS}

Outbred, Hartley strain guinea pigs (Camm Research Inst., Wayne, NJ) were obtained near term (68-72 days) of their second gestation. Upon arrival, the animals were caged individually in a room with $50 \%$ humidity, constant temperature $\left(22^{\circ} \mathrm{C}\right)$ and a 12 $\mathrm{h}$ light-dark cycle. A standard guinea pig diet and water were provided ad libitum. At the time of study the gestational age of the animals, extrapolated from fetal weights $(12,13)$, was estimated to be between 60 and 67 days.

The technique to measure ascorbic acid (AA) transfer in an in situ preparation has been described in detail elsewhere (20). Briefly, cannulae were inserted into the maternal jugular vein and carotid artery and a venous blood sample was obtained to establish base-line AA and glucose $(G)$ levels. The uterus was exposed through a midline abdominal incision and a fetus, whose placenta was positioned to allow easy access to all vessels, was chosen. The umbilical vein and an umbilical artery were cannulated. The fetus was removed and the placenta perfused $(1 \mathrm{ml} / \mathrm{min})$ with calf serum and saline $(1: 1, \mathrm{v} / \mathrm{v})$ via the umbilical artery. Perfusion fluid was warmed to $38^{\circ} \mathrm{C}$ before entering the placenta by passage through a coil submerged in the saline bath in which the lower half of the guinea pig was immersed. Blood levels of AA and G then were increased by infusion $(4.3 \mathrm{ml} / \mathrm{h})$ into the maternal jugular vein. This infusion fluid contained either AA alone or AA and $G$ dissolved in lactated Ringer's solution. Both solutions were prepared immediately before use with L-ascorbic acid and Dglucose (36). Perfusate leaving the umbilical vein was not recirculated but collected at $3-\mathrm{min}$ intervals yielding $3-\mathrm{ml}$ samples. After an initial $10 \mathrm{~min}$ of placental perfusion, maternal infusion began into the jugular vein. Maternal blood samples were taken before the placental perfusion period and at 15 -min intervals throughout the infusion period via the carotid artery. Similarly, blood samples were obtained whenever possible from the umbilical vein of fetuses left in utero before and after maternal infusion. At the conclusion of each experiment $(90 \mathrm{~min})$, placentas were retained for analysis. Maternal blood pressure and heart rate were monitored throughout each experiment by a transducer (Statham, Hato Rey, PR) attached to tubing from the carotid artery and connected to a polygraph (Grass Instrument Co., Quincy, MA).

All samples of plasma, placental homogenate and perfusate either remained on ice for prompt assay or were deproteinized and stored $\left(-20^{\circ} \mathrm{C}\right)$ for assay within 3 days $(20)$. Measurements of AA were performed using the Bessey et al. (1) modification of the 2,4 dinitrophenylhydrazine method. Assays of AA and blood $\mathrm{G}$ from dams infused with $A A$ and $G$ were performed immediately upon completion of an experiment. Glucose levels in plasma and perfusate were determined by a glucose oxidase method (Gluco-Stat, General Diagnostics, Morris Plains, NJ). 
Differences in means between values obtained after AA infusion with and without glucose were tested using the Student's $t$ test. The relationship between maternal and fetal plasma levels before and after AA infusion was analyzed using simple regression techniques. To determine whether there was a difference in the relationship between maternal and fetal levels in the group exposed to AA and $\mathrm{G}$ and the group exposed to AA alone, an F test was used. Multiple regression analyses were used to estimate the relationship between the amount of AA crossing the placenta per min per $\mathrm{g}$ of placenta and maternal plasma AA concentration holding maternal plasma $G$ levels constant. Analysis of covariance was used to determine if a statistically significant difference occurred between the $G$ and the non-G experiments $(8,14)$.

\section{RESULTS}

At the beginning of surgery, blood pressure for all animals was within the normal range for guinea pigs (19), systolic $80 \pm 7$ $\mathrm{mmHg}$ and diastolic $53 \pm 5 \mathrm{mmHg}(\overline{\mathrm{x}} \pm \mathrm{S}$.E.). Upon opening the abdomen the systolic and diastolic blood pressure dropped to 49 $\pm 3 \mathrm{mmHg}$ and $26 \pm 4 \mathrm{mmHg}$, respectively. This lowered blood pressure remained stable throughout the remainder of each experiment. Heart rate was stable and normal throughout each study, $218 \pm 8(\bar{x} \pm$ S.E.) beats per min (19). Significant differences in these parameters were not found among the 14 animals infused with AA alone and the four dams infused with the combination $A A$ and $G$ solution $(A A+G)$.

The perfused placentas and the fetuses from the perfused placentas did not differ significantly in weight from the nonperfused placentas and fetuses among the dams infused with either AA or $\mathrm{AA}+\mathrm{G}$. Each dam was infused with a single solution of AA or $\mathrm{AA}+\mathrm{G}$. Preinfusion levels of AA in maternal plasma were 0.29 \pm 0.02 (S.E.) $\mathrm{mg} / \mathrm{dl}$ and maternal infusion of either AA or AA

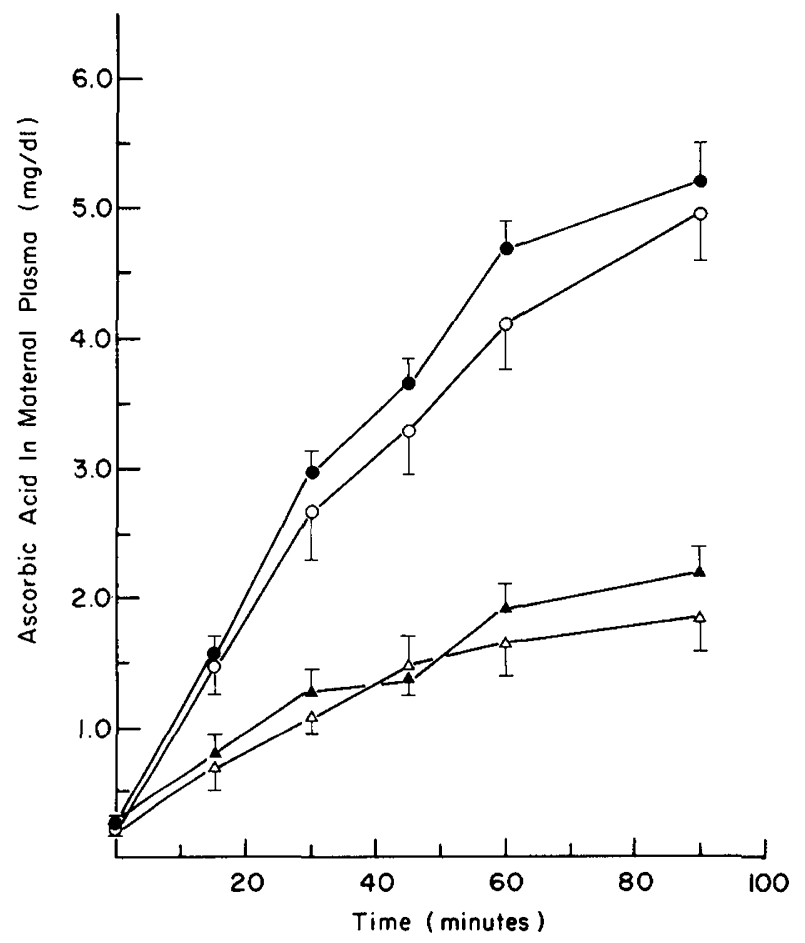

Fig. 1. Changes in maternal plasma ascorbic acid concentration among nine animals of nearly identical body weight (36) that were infused with either ascorbic acid alone $(\boldsymbol{\Lambda}, \mathbf{\Lambda})$ or ascorbic acid and glucose $(O, \triangle)$. At the end of each experiment, maternal plasma values among dams infused with ascorbic acid at $0.7 \mathrm{mg} / \mathrm{dl}(\boldsymbol{\Delta}, \triangle)$ and $1.0 \mathrm{mg} / \mathrm{dl}(\bullet, O)$ are both significantly different from preinfusion levels $(P<0.025)$. The group infused with $1.0 \mathrm{mg} / \mathrm{dl}$ ascorbic acid $(\bullet)$ had three animals whereas the other groups had two animals each. The results are expressed as means \pm S.E.

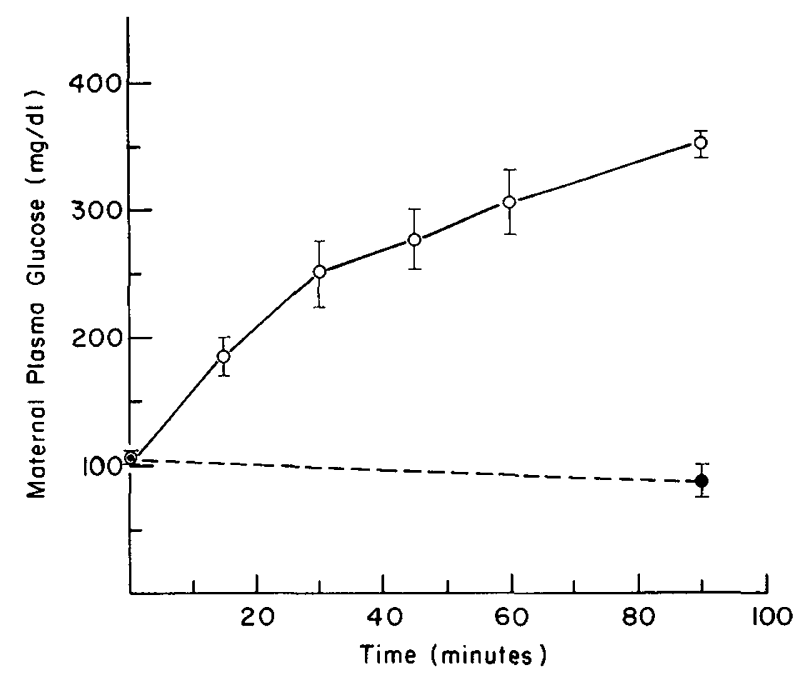

Fig. 2. Changes in maternal plasma glucose concentration among four dams infused with ascorbic acid and glucose $(O)$ and five dams infused with only ascorbic acid $(\bullet)$. Zero time maternal plasma glucose levels are computed from all nine animals. At the end of each experiment the plasma glucose concentration among dams infused with ascorbic acid and glucose were significantly different from both the zero time values $(P<0.001)$ and the postinfusion glucose values among dams infused with only ascorbic acid $(P<0.001)$. Each point represents the mean \pm S.E.

$+\mathrm{G}$ produced significant increases in maternal plasma AA levels ( $P<0.025$, Fig. 1). Similarly, the levels of $\mathrm{G}$ in maternal plasma increased from $104 \pm 4$ (S.E.) $\mathrm{mg} / \mathrm{dl}$ before $\mathrm{AA}+\mathrm{G}$ infusion to $370 \pm 19$ (S.E.) $\mathrm{mg} / \mathrm{dl}$ at the end of each study $(P<0.001$, Fig. 2$)$. Plasma $G$ levels among five dams infused with only AA were 93 \pm 6 (S.E.) $\mathrm{mg} / \mathrm{dl}$ after the infusion period. Before the maternal infusion, AA levels in fetal plasma, $0.46 \pm 0.03$ (S.E.) $\mathrm{mg} / \mathrm{dl}$, were significantly higher than maternal plasma values $(P<0.001)$ Maternal infusion of either AA or AA $+G$ significantly increased the AA concentration in 24 fetal plasma samples to $0.92 \pm 0.06$ (S.E.) $\mathrm{mg} / \mathrm{dl}(P<0.00 \mathrm{l})$; however, during AA $+\mathrm{G}$ infusion lower fetal plasma levels were observed than during maternal infusion of AA alone $(P<0.005$, Fig. 3$)$. These results suggest that when maternal plasma $\mathrm{G}$ concentration is increased the transport of AA to the fetus is reduced.

Preinfusion levels of $\mathrm{AA}$ in placental tissue were $10.8 \pm 0.5$ (S.E.) $\mathrm{mg} / 100 \mathrm{~g}$ of tissue and infusion of either AA or $\mathrm{AA}+\mathrm{G}$ produced significant increases in the AA content of all placentas that were examined, $39.6 \pm 3.3$ (S.E.) $\mathrm{mg} / 100 \mathrm{~g}$ of tissue $(P<$ $0.001)$. Further, a comparison of the $\mathrm{AA}$ in the placental tissue from dams infused with either $\mathrm{AA}$ or $\mathrm{AA}+\mathrm{G}$ demonstrates that significantly less AA was present in this organ after maternal infusion of $\mathrm{AA}+\mathrm{G}(P<0.005$, Fig. 4).

Because the concentration of $\mathrm{AA}$ in the perfusate leaving the placenta was measured and the rate of placental perfusion and the placental weight were known, it was possible to calculate the nmoles of AA that crossed the placenta per min, per $g$ of placenta. Figure 5 shows these data plotted against maternal plasma AA concentration when either AA or AA $+\mathrm{G}$ were infused. Analysis of these data revealed a significant decrease in AA transferred, expressed as nmoles of AA per min, per $g$ of tissue when $A A+G$ was infused (Fig. 5). For all maternal plasma AA levels among dams infused with $\mathrm{AA}+\mathrm{G}$ corresponding maternal plasma $\mathrm{G}$ levels were known. Accordingly, multiple regression analysis was used to estimate the relationship between maternal plasma AA and the amount of AA crossing the placenta holding maternal plasma $G$ levels constant. This analysis determined that placental transport of AA was decreased significantly $(P<0.001)$ when AA $+\mathrm{G}$ was administered. Finally, analysis of covariance was used to determine if a statistically significant difference in AA transport occurred between dams infused with $\mathrm{AA}$ and those given $\mathrm{AA}+$ $G$ (Table 1). Placental transport of AA was not affected at 


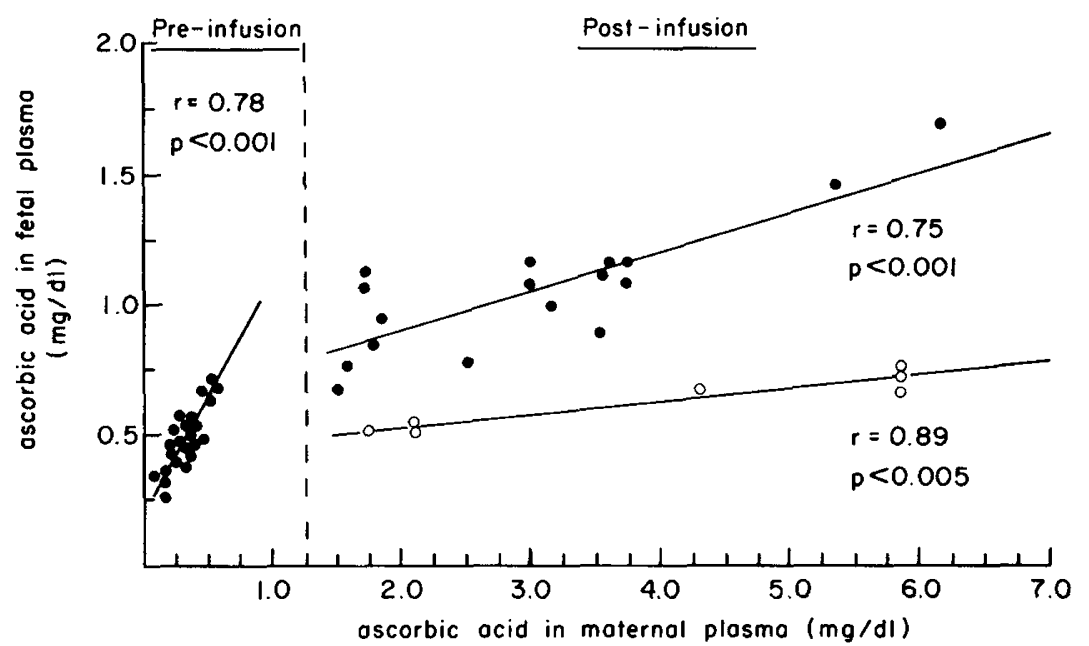

Fig. 3. The relationship between maternal and fetal plasma ascorbic acid concentrations before and after maternal infusion of either ascorbic acid alone $(\bullet)$ or ascorbic acid and glucose $(O)$. The estimated regression equations are: preinfusion, $y=0.20+0.90 x$; after ascorbic acid infusion, $y=0.60$ $+0.15 x$; after ascorbic acid and glucose infusion, $y=0.42+0.05 x$. Fetal ascorbic acid levels after ascorbic acid and glucose infusion were significantly below fetal levels found after infusion of ascorbic acid alone $(P<0.005)$. Each point represents a single observation.

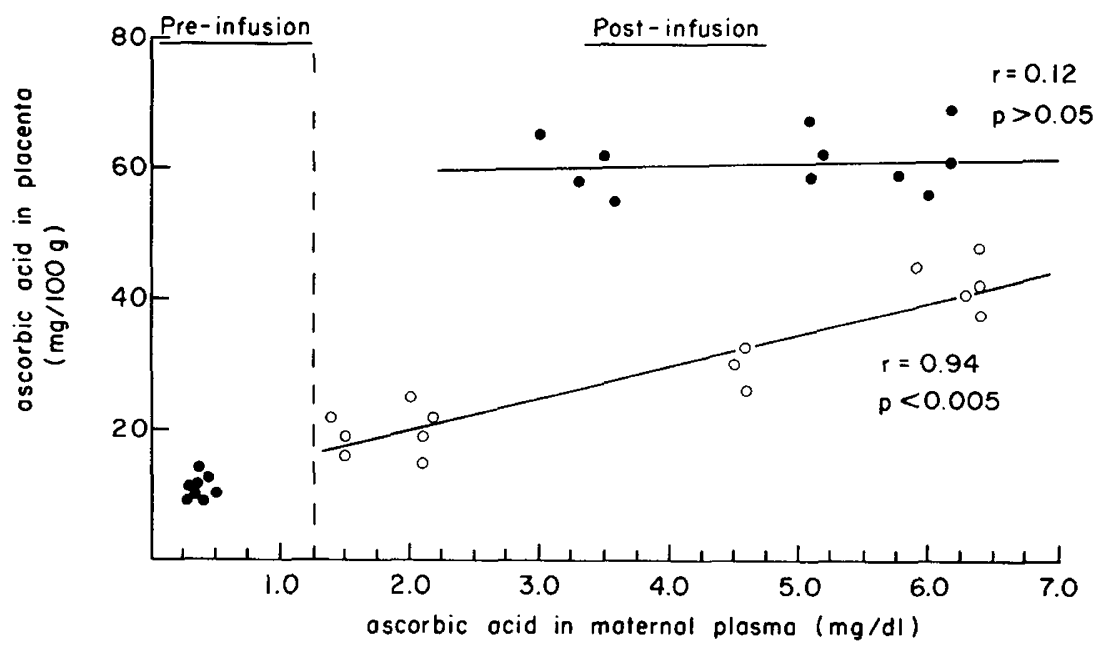

Fig. 4. The relationship between maternal plasma ascorbic acid levels and placental tissue ascorbic acid concentrations before and after maternal infusion of either ascorbic acid alone $(\Theta)$ or ascorbic acid and glucose $(O)$. The estimated regression equations are: preinfusion, $y=9.6+3.6 x$; after ascorbic acid infusion, $y=58.7+0.4 x$; after ascorbic acid and glucose infusion, $y=10.6+4.8 \mathrm{x}$. All postinfusion values are significantly different from preinfusion levels $(P<0.001)$. Placental tissue ascorbic acid levels after ascorbic acid and glucose infusion were significantly lower than placental ascorbic acid concentrations found when only ascorbic acid was infused $(P<0.005)$. Each point represents a single observation.

maternal plasma glucose levels below $200 \mathrm{mg} / \mathrm{dl}$; however, at maternal plasma glucose levels between $201-250 \mathrm{mg} / \mathrm{dl}$ significantly less AA crossed the placenta per min, per $\mathrm{g}$ of placenta $(P$ $<0.01$ ). At maternal plasma $G$ levels above $250 \mathrm{mg} / \mathrm{dl}$, the significance level of this decreased AA transport increased $(P<$ 0.001 , Table 1).

\section{DISCUSSION}

Previous reports from this laboratory have demonstrated that AA is transported across the placenta by a carrier-mediated mechanism in the rat, guinea pig, and man $(20,24,33)$. Present data suggest that in the guinea pig, glucose may compete with AA for the placental carrier and decrease the bioavailability of AA to the fetus. Therefore, maternal hyperglycemia during pregnancy may affect the placental transfer of AA in man.

In both the depancreatized $\operatorname{dog}(22)$ and the streptozotocindiabetic rat (35), the serum level of AA is decreased relative to the nondiabetic animal whereas urinary excretion of the vitamin is increased. Lower serum AA levels have also been reported among diabetic humans $(2,3,5,27)$. Although these studies did not attempt to correlate these findings with blood $\mathrm{G}$ levels, they are consistent with an hypothesis that the bioavailability of AA is reduced in diabetes mellitus.

Two studies have estimated the tissue AA status of the diabetic individual by measuring the concentration of AA in leucocytes. One group of 127 diabetic subjects was found to have lower leucocyte AA levels than the nondiabetic controls (5) whereas a second group of 44 diabetic patients had leucocyte AA levels that were similar to control subjects (27). Other studies that have examined the tissue levels of AA in diabetes indicate that platelets from diabetic humans (25) and liver tissue from alloxan-diabetic rats (23) also have lower AA content than control specimens. In addition, the present study suggests that placental tissue AA levels may be affected by maternal hyperglycemia. A comparison of the placental tissue AA levels among animals infused with either AA alone or $\mathrm{AA}+\mathrm{G}$ demonstrates that significantly less $\mathrm{AA}$ is present in placental tissue from dams infused with $A A+G$.

Vitamin $\mathrm{C}$ exists in blood and tissues in two biologically active forms, either the reduced L-ascorbic acid (LAA), or the oxidized dehydroascorbic acid (DHA). Both forms possess $100 \%$ biologic activity (6); however, it appears that DHA is the only form of the 


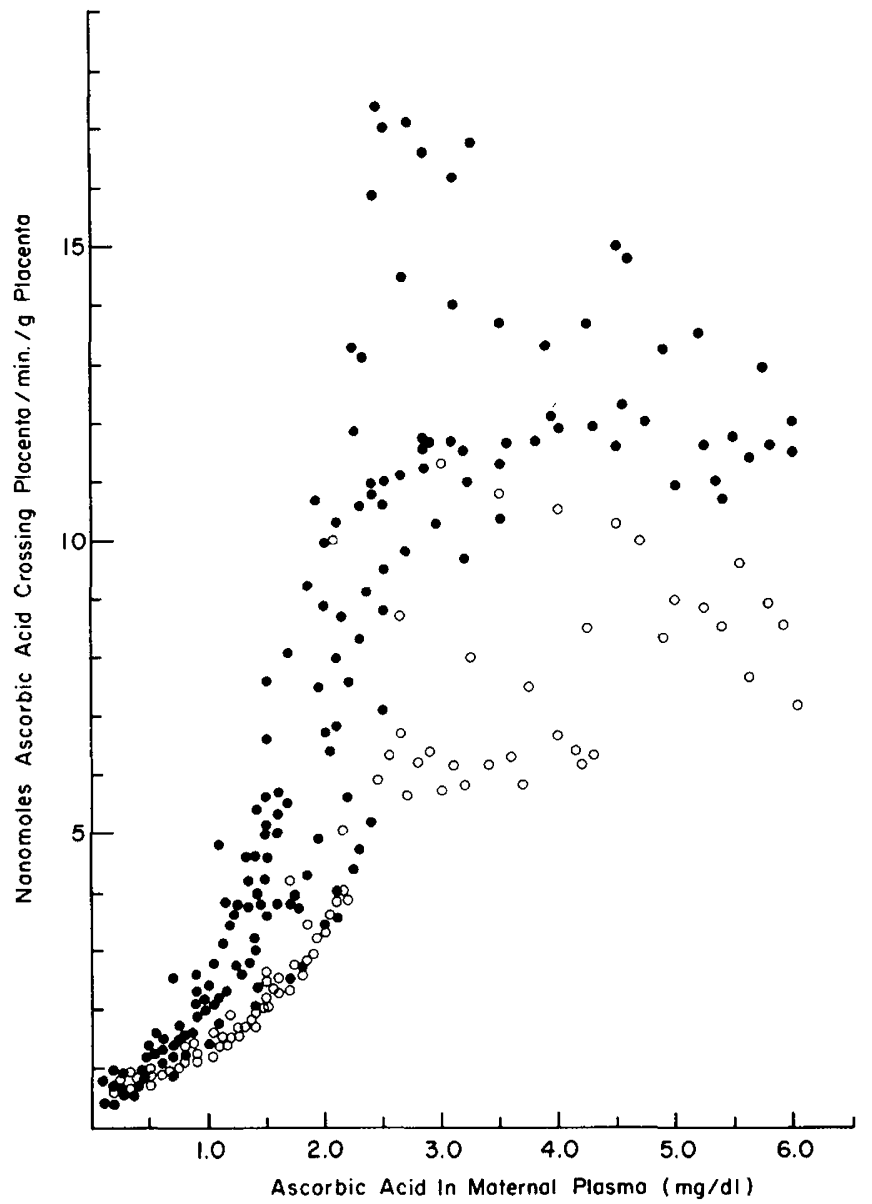

Fig. 5. The effect of maternal plasma ascorbic acid concentrations on the transfer of ascorbic acid by the guinea pig placenta (nmoles per min per $g$ placenta) when either ascorbic acid alone $(\Theta)$ or ascorbic acid and glucose $(O)$ were infused into the dam. Each point represents one observation. Multiple regression analysis was used to estimate the relationship between maternal plasma ascorbic acid and the nmoles of ascorbic acid crossing the placenta per min per $\mathrm{g}$ placenta holding maternal plasma glucose levels constant $\left(y=-0.27+0.67 x-0.08 x^{2}-0.16\right.$ glucose $)$. When ascorbic acid and glucose were infused, the nmoles of ascorbic acid crossing the placenta per $\mathrm{g}$ of placenta were significantly less than when ascorbic acid alone was infused $(P<0.001)$.

Table 1. Significance levels and $t$ values for the analyses of covariance $^{1}$

\begin{tabular}{cccc}
\hline & \multicolumn{3}{c}{ Independent variables } \\
\cline { 2 - 4 } Maternal plasma glucose $(\mathrm{mg} / \mathrm{dl})$ & $\mathrm{x}$ & $\mathrm{x}^{2}$ & Glucose \\
\hline $0-120$ & $<0.001$ & & $>0.40$ \\
& $(6.310)$ & & $(0.779)$ \\
$121-200$ & $<0.001$ & $<0.001$ & $>0.10$ \\
& $(9.402)$ & $(4.651)$ & $(1.840)$ \\
$201-250$ & $<0.001$ & $<0.001$ & $<0.01$ \\
& $(9.779)$ & $(6.319)$ & $(2.786)$ \\
$251-300$ & $<0.001$ & $<0.001$ & $<0.001$ \\
& $(10.049)$ & $(7.270)$ & $(3.640)$ \\
$301-350$ & $<0.001$ & $<0.001$ & $<0.001$ \\
& $(12.136)$ & $(9.286)$ & $(6.098)$ \\
$>350$ & $<0.001$ & & $<0.001$ \\
& $(7.934)$ & & $(4.820)$ \\
\hline
\end{tabular}

\footnotetext{
${ }^{1}$ For the analyses, the dependent variable equaled the nmoles of ascorbic acid crossing the placenta per min per $g$ of placenta. Regressions were run for six different levels of maternal plasma glucose; $x=$ maternal plasma ascorbic acid concentration; glucose $=$ one if dams were infused with $\mathrm{AA}+\mathrm{G}$ and glucose = zero if dams were infused with AA only. $t$ values are shown in the parenthesis.
}

vitamin that is transported by the carrier-mediated process $(10$, $11,18,20,21)$. This may explain why diabetic subjects have been reported to have higher levels of DHA in their plasma than nondiabetic individuals $(2,3,27)$.

The present study indicates that an acute episode of maternal hyperglycemia $(>200 \mathrm{mg} / \mathrm{dl})$ can reduce markedly the AA that is transferred by the guinea pig placenta. These experiments have not explored the effect of chronic maternal hyperglycemia during pregnancy. Still, the possible implications of the present finding for the gestational diabetic deserve further attention particularly because many similarities have been suggested between the various angiopathies associated with diabetes mellitus and the degeneration of vascular tissue that accompanies ascorbic acid deficiency $(16,17,33)$.

\section{REFERENCES AND NOTES}

1. Bessey, O., Lowry, O., and Brock, M.: The quantitative determination of ascorbic acid in small amounts of white blood cells and platelets. J. Biol. Chem., 168: 197 (1947).

2. Chatterjee, I. B. and Banerjee, A.: Estimation of dehydroascorbic acid in the blood of diabetic patients. Anal. Biochem., 98: 368 (1979).

3. Chatterjee, I. B., Majunder, A. K., Nandi, B. K., and Subramian, N.: Synthesis and some major functions of vitamin $\mathrm{C}$ in animals. Ann. N. Y. Sci., 258: 24 (1975).

4. Finn, F. M. and Johns, P. A.: Ascorbic acid transport by isolated bovine adrenal cortical cells. Endocrinology, 106: 811 (1980).

5. Ginter, E., Zdichznec, B., Holzerova, O., Ticha, E., Kobza, R., Koiakova, M., Cerra, O., Ozdin, L., Hruba, F., Novakova, V., Sasko, E., and Gaher, M.: Hypocholestrolemic effects of ascorbic acid in maturity-onset diabetes mellitus. Internat. J. Vit. Nutr. Res., $48: 369$ (1978).

6. Harris, R. E.: Active compounds and ascorbic acid antagonists. In: W. H. Sebrell and R. S. Harris, Ed.: The Vitamins, Chemistry, Physiology, Pathology, Methods, Vol. 1, second ed., pp. 383-384 (Academic Press, New York, NY, 1967).

7. Heath, H. and Fiddick, R.: The active transport of ascorbic acid by the rat retina. Explt. Eye Res., 5: 156 (1966).

8. Hoel, P.: In: Introduction to Mathematical Statistics, fourth ed., (John Wiley and Sons, Inc., New York, NY, 1971).

9. Hornig, D., Weber, F., and Wiss, O.: Autoradiographic distribution of $\left[1-{ }^{14} \mathrm{C}\right]$ ascorbic acid and $\left[1-{ }^{14} \mathrm{C}\right]$ dehydroascorbic acid in male guinea pigs after intravenous injection. Internat. J. Vit. Nutr. Res., 42: 223 (1972).

10. Hornig, D., Weber, F., and Wiss, O.: Uptake and release of $\left[1-{ }^{14} \mathrm{C}\right]$ ascorbic acid and $\left[1-{ }^{14} \mathrm{C}\right]$ dehydroascorbic acid by erythrocytes of guinea pigs. Clin. Chim. Acta, 31: 25 (1971).

11. Hornig, D., Weiser, H., Weber, F., and Wiss, O.: Uptake and release of $\left[1-{ }^{14} \mathrm{C}\right]$ ascorbic acid and $\left[1-{ }^{14} \mathrm{C}\right]$ dehydroascorbic acid by leucocytes of guinea pigs. Clin. Chim. Acta, 32: 33 (1971).

12. Hugget, A. and Widdas, W.: The relationship between fetal weight and conceptus age. J. Physiol., 114: 306 (1951).

13. Ibsen, $H .:$ Prenatal growth in guinea pigs with special reference to environmental factors affecting weight at birth. J. Exptl. Zool, 51: 51 (1928).

14. Johnston, J.: In: Econometric Methods. second ed., (McGraw-Hill Book Co., New York, NY, 1972)

15. Linner, E. and Nordstrom, K.: Transfer of D-isoascorbic acid and L-ascorbic acid into guinea pig eyes. Documenta Ophthal. (Den Haag), 26: 164 (1969).

16. Mann, G. V.: Hypothesis: the role of vitamin $C$ in diabetic angiopathy. Perspect. Biol. Med., 17: 210 (1973).

17. Mann, G. V. and Newton, P.: The membrane transport of ascorbic acid. Ann. N. Y. Acad. Sci., 258: 234 (1975).

18. Martin, G. R. and Mecca, C. E.: Studies on the distribution of L-ascorbic acid in the rat. Arch. Biochem. Biophys., 93: 110 (1961).

19. Marshall, L. H. and Hanna, C. H.: Direct measurement of arterial blood pressure in the guinea pig. Proc. Soc. Exp. Biol. Med., 92: 31 (1956).

20. Norkus, E. P., Bassi, J., and Rosso, P.: Maternal-fetal transfer of ascorbic acid in the guinea pig. J. Nutr., 109: 2205 (1979).

21. Raiha, N.: On the placental transfer of vitamin C: an experimental study on guinea pigs and human subjects. Acta Physiol. Scand., 45 (suppl. 155): 1 (1958).

22. Ralli, E. P. and Sherry, S.: Effect of insulin on plasma level and excretion of vitamin C. Proc. Soc. Exp. Biol. Med., 43: 669 (1940).

23. Rikans, L. E.: Effect of alloxan diabetes on rat liver ascorbic acid. Horm. Metab. Res., 13: 123 (1981)

24. Rosso, P. and Norkus, E.: Prenatal aspects of ascorbic acid metabolism in the albino rat. J. Nutr., 106: 767 (1976).

25. Sarji, K, E., Kleinfeller, J., Brewington, P., Gonzalez, J., Hempling, $H_{\text {, and }}$ Colwell, J. A.: Decreased platelet vitamin C in diabetes mellitus: possible role in hyperaggregation. Thrombosis Res., 15: 639 (1979).

26. Sharma, S., Johnstone, R., and Quastel, J.: Active transport of ascorbic acid in adrenal cortex and brain cortex in vitro, and the effects of ACTH and steroids. Can. J. Biochem. Physiol., 41: 597 (1963).

27. Som, S., Basu, S., Mukherjee, D., Deb, S., Roy Choudhury, P., Mukherjee, S., Chatterjee, S. N., and Chatterjee, I. B.: Ascorbic acid metabolism in diabetes mellitus. Metabolism, 30: 572 (1981).

28. Spector, R. and Greene, L.: Ascorbic acid transport by a clonal line of pheochromacytoma cells. Brain Res., 136: 131 (1977). 
29. Spector, R. and Lorenzo, A.: Ascorbic acid homeostasis in the central nervous system. Am. J. Physiol., 225: 757 (1973).

30. Spector, R. and Lorenzo, A.: Specificity of ascorbic acid transport of the central nervous system. Am. J. Physiol., 226: 1468 (1974).

31. Stevenson, N.: Active transport of $\mathrm{L}$-ascorbic acid in the human ileum. Gastroenterology, 67: 952 (1974).

32. Stevenson, N. and Brush, M.: Existence and characteristics of sodium-dependent active transport of ascorbic acid in the guinea pig. Am. J. Clin. Nutr., 22: 308 (1969).

33. Streeter, M. and Rosso, P.: Transport mechanisms for ascorbic acid in the human placenta. Am. J. Clin. Nutr., 34: 1706 (1981).

34. Verlangieri, A. J. and Sestito, J.: Effect of insulin on ascorbic acid uptake by heart endothelial cells: possible relationship to retinal atherogenesis. Life Sci., 29: 5 (1981).

35. Zebrowski, E. J. and Bhatnager, P. K.: Urinary excretion pattern of ascorbic acid in streptozotocin diabetic and insulin treated rats. Pharm. Res. Commun., 11: 95 (1979).

36. Dams used in this study $(n=18)$ weighed $1342 \pm 110 \mathrm{~g}$ (S.D.) and thus their plasma volumes varied $[4.4 \pm 0.3 \mathrm{ml}(\mathrm{S} . \mathrm{E}.) / 100 \mathrm{~g}$ body weight, Sisk, D.: Physiology. In: J. E. Wagner and P. J. Manning, ed., The Biology of the Guinea pig, pp 63-92, (Academic Press, New York, NY, (1976)]. In an attempt to standardize the doses of ascorbic acid and glucose that were administered to all animals per ml of plasma volume, the maternal infusion solutions contained $\mathrm{L}$-ascorbic acid and D-glucose at concentrations of $0.06-0.08 \mathrm{M}$ and $1.7-2.0 \mathrm{M}$ respectively.

37. This research was partially supported by grants HD10167 and HDI0016 (Career Development Award).

38. The work reported in this paper was submitted by E. P. Norkus as part of his Ph.D. dissertation, Columbia University, 1979.

39. Present address: Dept of Biochemistry and Drug Metabolism, Hoffmann-La Roche Inc., Nutley, New Jersey 07110.

40. Requests for reprints should be addressed to: Dr. E. P. Norkus, Department of Biochemistry and Drug Metabolism, Hoffmann-La Roche Inc., Nutley, NJ 07110.

41. Received for publication May 7, 1981.

42. Accepted for publication March 10, 1982. 